STUDI PEMBUATAN TAPE SINGKONG (Manihot utilissima) DENGAN PENAMBAHAN SARI BUAH NANAS

(Ananas comosus)

Oleh :

IRIANTO

202091010005

SKRIPSI

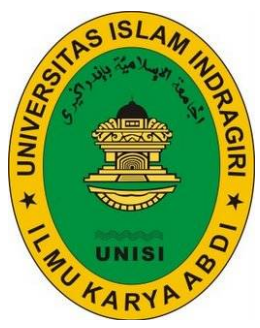

PROGRAM STUDI TEKNOLOGI PANGAN

FAKULTAS PERTANIAN

UNIVERSITAS ISLAM INDRAGIRI

2012 


\title{
SKRIPSI
}

\section{STUDI PEMBUATAN TAPE SINGKONG (Manihot utilissima) DENGAN PENAMBAHAN SARI BUAH NANAS \\ (Ananas comosus)}

Oleh :

\author{
IRIANTO \\ 202091010005
}

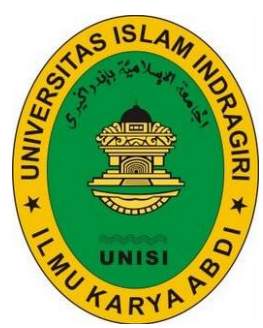

Diajukan Sebagai Salah Satu Syarat Untuk Dapat Memperoleh

Gelar Sarjana

Pada Program Studi Teknologi Pangan Fakultas Pertanian

Universitas Islam Indragiri

\section{PROGRAM STUDI TEKNOLOGI PANGAN \\ FAKULTAS PERTANIAN \\ UNIVERSITAS ISLAM INDRAGIRI \\ 2012}




\section{SKRIPSI}

\section{STUDI PEMBUATAN TAPE SINGKONG (Manihot utilissima) DENGAN PENAMBAHAN SARI BUAH NANAS (Ananas comosus)}

Oleh

\section{IRIANTO}

202091010005

\section{Menyetujui:}

Pembimbing I

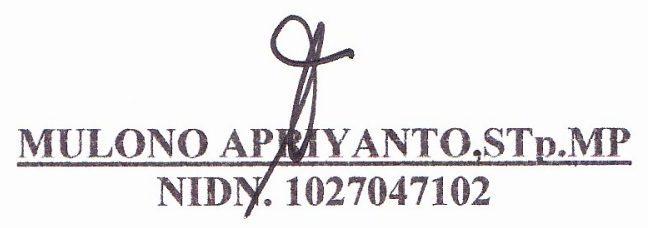

Mengetahui :
Dekan Fakultas Pertanian

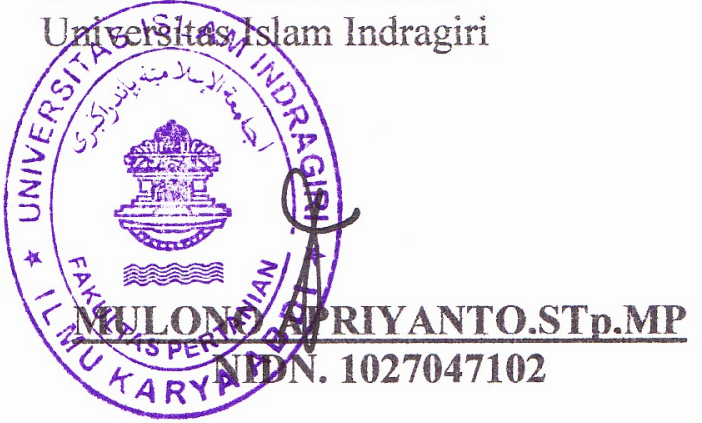

Pembimbing II

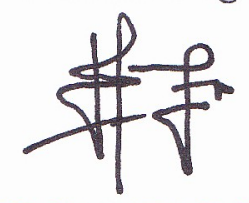

SUSI SALHAN,SP.MP

NIDN. 1018067601
Ketua Program Studi

Teknologi Pangan

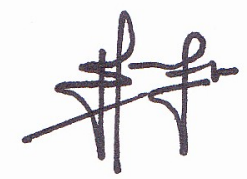

SUSI SALHAN,SP.MP

NIDN. 1018067601 


\title{
SKRIPSI
}

\section{STUDI PEMBUATAN TAPE SINGKONG (Manihot utilissima) DENGAN PENAMBAHAN SARI BUAH NANAS (Ananas comosus)}

\author{
Yang dipersiapkan dan disusun oleh \\ Irianto \\ 202091010005
}

Telah dipertahankan didepan Dewan Penguji

pada tanggal 19 Februari 2012 serta dinyatakan lulus dan disetujui sebagai syarat kelengkapan jenjang studi Strata Satu (S-1) Program studi

Teknologi Pangan Fakultas Pertanian Universitas Islam Indragiri

\section{Susuanan Dewan Penguji}
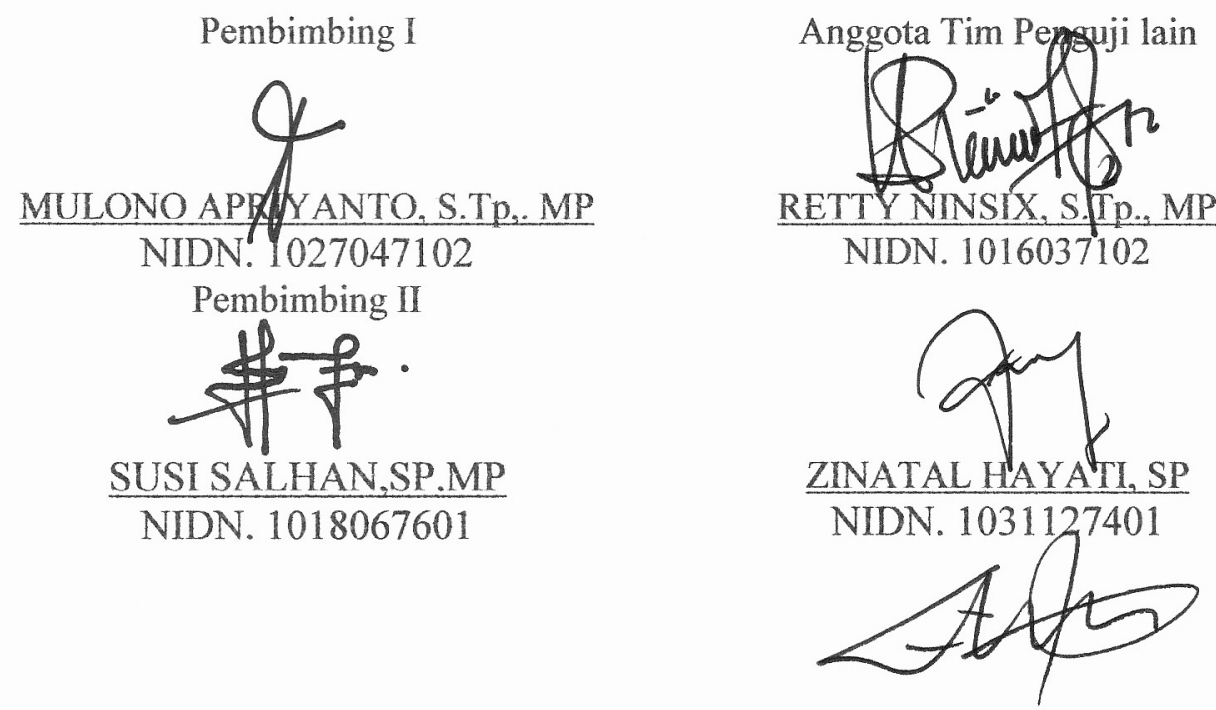

$\frac{\text { AGUS NUROSO, S.Tp }}{\text { NIDN. } 1010088102}$

Skripsi ini telah diterima sebagai salah satu persyaratan

Untuk memperoleh gelar sarjana

Tanggal 19 Februari 2012

Pengelola Program Studi Teknologi Pangan 


\title{
STUDI PEMBUATAN TAPE SINGKONG (Manihot utilissima) DENGAN PENAMBAHAN SARI BUAH NANAS \\ (Ananas comosus)
}

\begin{abstract}
Abtrak
Tujuan penelitian ini adalah untuk mengetahui pengaruh pemberian sari buah nanas terhadap mutu tape ubi kayu. Pembuatan tape singkong dengan penambahan sari buah nanas diberi perlakuan pendahuluan dengan sortasi bahan baku pembuatan tape singkong dan nanas yang digunakan, pengupasan, pemotongan, pembersihan, perebusan hingga setengah matang, penirisan, pendinginan, penambahan ektrak nanas dengan berbagai variasi yaitu $25 \mathrm{ml}, 35$ $\mathrm{ml}$, $45 \mathrm{ml}$ dan dilakuan dengan 3 kali ulangan, pengukusan, pendinginan, pemberian ragi, fermentasi. Analisa dilakukaan untuk penentuan kadar protein, kadar alcohol, kadar gula reduksi, total asam, pH, TSS, organoleptik warna, rasa, aroma dan tekstur.

Hasil penelitian menunjukan bahwa kombinasi perlakuan penambahan sari buah nanas berpengaruh terhadap analisa yang dilakukan. Semakin tinggi volume sari buah nanas semakin tinggi pula kadar protein, kadar alcohol dan kadar total soluble solid dan gula reduksi, kadar total asam dan $\mathrm{pH}$ semakin menurun.
\end{abstract}

Kata kunci : ubi kayu (singkong), ektrak nenas, fermentasi. 